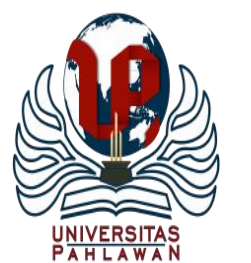

Edukatif : Jurnal Ilmu Pendidikan Volume 3 Nomor 6 Tahun 2021 Halm 3500 - 3508

EDUKATIF: JURNAL ILMU PENDIDIKAN

Research \& Learning in Education

https://edukatif.org/index.php/edukatif/index

\title{
Pengembangan Lembar Kerja Peserta Didik (LKPD) Bermuatan Budaya Lokal untuk Anak Usia Dini
}

\section{Chresty Anggreani}

Pendidikan Guru Anak Usia Dini, Universitas Lambung Mangkurat, Indonesia

E-mail : chresty.anggreani@ulm.ac.id

\begin{abstract}
Abstrak
Penelitian ini bertujuan untuk menghasilkan lembar kerja peserta didik (LKPD) berbasis budaya lokal Kalimantan Selatan dengan menggunakan metode penelitian dan pengembangan Research and Development $(R \& D)$. Prosedur penelitian yang digunakan dalam pengembangan ini menggunakan langkah model Dick \& Carey. Subjek dari penelitian ini yaitu anak kelompok B di TK Negeri Banjarmasin Timur. Pengumpulan data dilakukan dengan wawancara, lember observasi, dan angket. Hasil penelitian menunjukan bahwa lembar kerja peserta didik berbasis budaya lokal Kalimantan Selatan yang dikembangkan sudah memenuhi kriteria valid, praktis, dan efektif . LKPD anak berbasis budaya Kalimantan Selatan ini sangat sesuai digunakan pada anak usia dini untuk menstimulasi aspek perkembangan anak.
\end{abstract}

Kata Kunci: Lembar Kerja Peserta Didik, Budaya Lokal, PAUD.

\begin{abstract}
This study aims to produce student worksheets based on the local culture of South Kalimantan using the Research and Development $(R \& D)$ research and development method. The research procedure used in this development uses the Dick \& Carey model step. The subjects of this study were children in group B in TK Negeri Banjarmasin Timur. Data collection was carried out by interview, observation table, and questionnaire. The results showed that the worksheets of students based on the local culture of South Kalimantan that was developed had met the criteria of being valid, practical, and effective. This South Kalimantan culture-based children's activity book is very suitable for use in early childhood to stimulate aspects of child development.

Keywords: Student Worksheets, Local Culture, Early Childhood Education.
\end{abstract}

Copyright (c) 2021 Chresty Anggreani

$\triangle$ Corresponding author

Email : chresty.anggreani@ulm.ac.id

DOI $\quad$ : https://doi.org/10.31004/edukatif.v3i6.882

ISSN 2656-8063 (Media Cetak)

ISSN 2656-8071 (Media Online) 
3501 Pengembangan Lembar Kerja Peserta Didik (LKPD) Bermuatan Budaya Lokal untuk Anak Usia DiniChresty Anggreani

DOI $\quad$ : https://doi.org/10.31004/edukatif.v3i6.882

\section{PENDAHULUAN}

Indonesia merupakan negara kepulauan yang luas dan memiliki keragaman kebudayaan. warisan kebudayaan tersebut sudah berkembang dari beribu abad tahun yang lalu. Warisan kebudayaan tersebut beragam dan mempunyai kekhasan masing-masing. Warisan budaya tersebut memuat: nilai luhur, nilai kebaikan, teknologi, arsitektur, kesenian, dll. Aktivitas masyarakatnya pun berpegang teguh pada nilai-nilai kebudayaan tersebut yang duturunkan secara turun temurun, misalnya nilai kesopanan, keramahan, gotong royong, dsb. Wijiningsih et al (2017) menyebutkan budaya lokal adalah budaya daerah yang dimiliki oleh suatu masyarakat yang berkembang dan mengakar. Sedangkan Brata (2016) mengungkapkan bahwa modal utama dalam pengembangan identitas Ke-Indonesian adalah melalui kebudayaan. Dengan demikian, budaya sebagai identitas yang dimiliki oleh suatu masyarakat.

Derasnya arus globalisasi pada saat ini dapat mempengaruhi tatanan budaya daerah. Mubah (2011) menyebutkan dampak kekuatan globalisasi mampu menggalahkan budaya lokal. Sehingga perlunya penanaman yang kuat mengenai budaya sebagai bentuk pelestarian untuk mencegah terjadinya kepunahan budaya. Penanaman tersebut dilakukan melalui penerapan budaya dalam kehidupan sehari-hari (Setyaningrum, 2018). Penanaman budaya harus dikenalkan kepada anak sejak dini sebagai bentuk pelestarian kepada generasi penerus agar tidak tergerus arus globalisasi. Peranan pendidikan anak usia dini (PAUD) dalam hal pelestarian sangat penting melalui pengintegrasian materi budaya lokal ke dalam kegiatan pembelajaran. Islamiah et al (2019) mengungkapkan salah satu tujuan pendidikan anak sebagai sarana dalam peningkatan potensi dan bakat anak. Salah satu potensi yang harus dikembangkan kepada anak adalah karakter atau nilai-nilai luhur yang diperoleh anak melalui budayanya. Wandari et al (2018) menyebutkan dengan pembelajari budaya dapat memberikan dan menciptakan pembelajaran yang lebih bermakna. Pengenalan budaya kepada anak dapat dilakukan menggunakan berbagai metode, media yang ada sekitar anak. Dengan menggunakan bahan ajar yang dekat dengan lingkungan anak dapat mengembangkan konsep pengetahuan dengan keterlibatan aktif anak. Sehingga diperlukan bahan ajar yang mendukung perkembangan anak tersebut (Ariyanti, 2016). Salah satunya menggunakan bahan ajar yang berbasis pada budaya lokal.

Penerapan penanaman konsep budaya tersebut dilakukan dengan menggunakan bahan ajar yang konkret salah satunya melalui LKPD (lembar kerja peserta didik) yang berbasis budaya lokal. Fungsi LKPD dalam kegiatan pembelajaran yakni sebagai sumber belajar dan alat ukur guru ke anak dalam sebuah aktivitas pembelajaran. Sebagaimana dari penelitian yang dilakukan oleh Ramadhan (2014) bahwa penggunaan LKS dapat digunakan untuk mengukur pemahaman dan minat belajar anak. (Herman \& Aslim, 2015), (Noprinda \& Soleh, 2019) menyebutkan LKPD merupakan perangkat operasional yang digunakan sebagai media dalam menciptakan keaktifan anak dalam pembelajaran. Sehingga, LKPD sebagai bahan ajar (Hulu \& Dwiningsih, 2021), juga sebagai sarana dalam pendukung guru untuk menyampaikan materi melalui penciptaan pembelajaran yang menarik dan menyenangkan.

Peneliti melakukan analisis mendalam tentang materi pada LKPD yang dimiliki oleh TK Negeri Pembina Banjarmasin Timur. Dari beberapa buku majalah tersebut peneliti belum menemukan adanya buku majalah yang mengaitkan pada materi budaya Kalimantan Selatan. Kebanyakan dari buku majalah tersebut membahas materi yang besifat umum tanpa mengandung unsur budaya lokal daerah setempat. Buku tersebut juga lebih mendominasi pada pengembangan aspek kognitif semata, padahal terdapat aspek pengembangan lainnya yang juga harus dikembangkan pada anak usia dini meliputi: perkembangan nilai, agama, dan moral, perkembangan sosial emosional, perkembangan bahasa, perkembangan fisik motorik. Kemudian, peneliti melakukan wawancara dengan guru-guru di TK Banjarmasin Timur tentang materi budaya lokal yang dikenalkan kepada anak sejak dini. Guru-guru tersebut berpandangan bahwa sangat penting memuat materi budaya lokal dalam buku LKPD, sebagai wujud dari pelestarian budaya itu sendiri kepada anak sedini mungkin. 
Berdasarkan permasalahan diatas, maka peneliti tertarik untuk mengembangkan LKPD berbasis budaya lokal. LKPD ini berisi materi dan kegiatan-kegiatan untuk mengenalkan anak pada budaya lokal yang sesuai dengan prinsip pembelajaran anak usia dini. LKPD sebagai sumber belajar digunakan guru untuk memudahkan dalam menyampaikan pembelajaran kepada anak. Sebagaimana yang diungkapkan oleh Fitriani et al (2016) bahwa LKPD digunakan untuk memudahkan pemahaman konsep bagi peserta didik. Dalam pengenalan budaya lokal menggunakan LKPD ini, peneliti menyajikannya dalam bentuk gambar-gambar yang berwarna menarik. Hal ini dilakukan untuk mempermudah dan meningkatkan keantusiasan anak dalam mempelajari budaya lokalnya, sehingga dapat meningkat keaktifan anak dalam kegiatan pembelajaran ((Rahayu, 2018).

Mengacu pada uraian diatas, maka tujuan dari penelitian adalah untuk mengembangkan LKPD berbasis budaya lokal yang valid, praktis untuk memenuhi kebutuhan bahan ajar di PAUD. Perbedaan penelitian yang dilakukan peneliti sebelumnya terkait dengan materi yang disajikan dalam LKPD, sehingga untuk memenuhi kebutuhan tersebut dikembangkan penelitian dengan judul "Pengembangan Lembar Kerjas Peserta Didik (LKPD) Berbasis Budaya Lokal”, yang berbeda dengan penelitian sebelumnya dengan memuat unsur-unsur budaya lokal dalam LKPD anak.

\section{METODE PENELITIAN}

Penelitian pengembangan menurut Borg \& Gall dikutip Setyosari (2016: 276) adalah suatu proses untuk digunakan dalam mengembangkan dan memvalidasi produk oleh pendidik melalui suatu langkah-langkah secara siklus. Model yang digunakan dalam penelitian ini adalah model pengembangan media Dick \& Carey dengan delapan (8) tahapan yakni: identifikasi alat ukur keberhasilan, penulisan naska media, tes uji coba, revisi, dan naska siap produksi. Berikut ini adalah prosedur penelitian pengembangan menggunakan model Dick \& Carey yang dikutip oleh Setyosari (2017: 284-289):

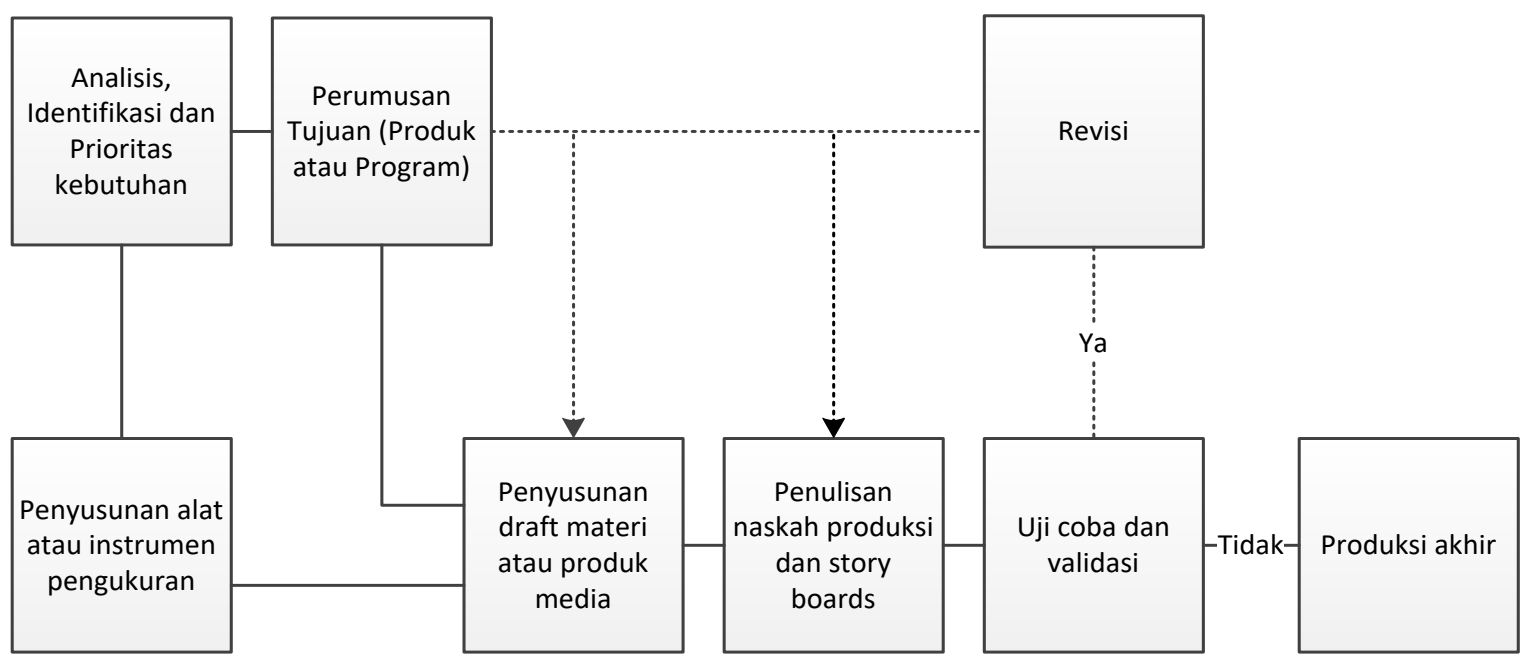

Gambar 1. Bagan Penelitian dan Pengembangan

\section{HASIL DAN PEMBAHASAN PENELITIAN}

Pengembangan LKPD berbasis budaya lokal dilakukan melalui beberapa langkah yaitu: pertama, peneliti melakukan pengumpulan data untuk mengidentifikasi masalah yang muncul. Identifikasi kebutuhan ini dilakukan dengan menganalisis LKPD atau buku majalah dari berbagai penerbit yang digunakan guru di kelompok B TK Pembina Banjarmasin Timur. Hasil analisis tersebut menunjukan 70\% buku LKPD yang 
3503 Pengembangan Lembar Kerja Peserta Didik (LKPD) Bermuatan Budaya Lokal untuk Anak Usia DiniChresty Anggreani

DOI : https://doi.org/10.31004/edukatif.v3i6.882

digunakan oleh guru belum sesuai dengan budaya lokal Kalimantan Selatan. Dan buku tersebut juga belum mengacu pada stimulasi pada aspek perkembangan anak. Dengan kata lain, buku tersebut masih belum sesuai dengan karakteristik anak usia dini. Sedangkan berdasarkan wawancara dengan guru di kelompok B TK Pembina Banjarmasin Timur bahwa guru sangat memerlukan LKPD berbasis budaya lokal Kalimantan Selatan untuk memudahkan guru dalam menyampaikan dan pengenalan materi budaya kepada anak. Setelah mempertimbangkan kekurangan dari LKPD yang sudah ada dan yang telah digunakan serta pentingnya materi budaya lokal dikenalkan pada anak usia dini, maka Peneliti mengembangkan LKPD anak berbasis budaya lokal Kalimantan Selatan.

Kedua, langkah ini merupakan perumusan tujuan yang akan dicapai dalam mengembangkan produk LKPD berbasis budaya lokal yang valid, praktis dan efektif yang memenuhi kebutuhan sumber belajar anak untuk mengembangkan aspek perkembangannya secara optimal. Tahapan ini terdiri dari: 1) pengembangan materi, materi yang digunakan dalam pelaksanaan penelitian ini yaitu materi pengenalan budaya Kalimantan Selatan meliputi: a) makanan khas banjar; soto banjar, ketupat kadangan, apam barabai, bingka barandam, pais pisang, dan pai waluh, b) Rumah adat; rumah adat Bubungan Tinggi, c) Pakaian; baju daya meratur, baju Nanang-Galuh , d) alat music; alat musik panting, e) seni tari; tari japin, f) permainan; balogo, cukcukbimbi, g) lagu daerah; ampa-ampar pisang, saputangan bapuncu ampat. Kemudian, selanjutnya peneliti juga membuat alat ukur berupa alat observasi untuk melihat keberhasilan anak dalam menggunakan produk buku aktivitas anak ini.

Ketiga, tahap ini merupakan penulisan naska LKPD anak yang dikembangkan. Desain awal LKPD ini menggunakan aplikasi photoshop dan paint tool.
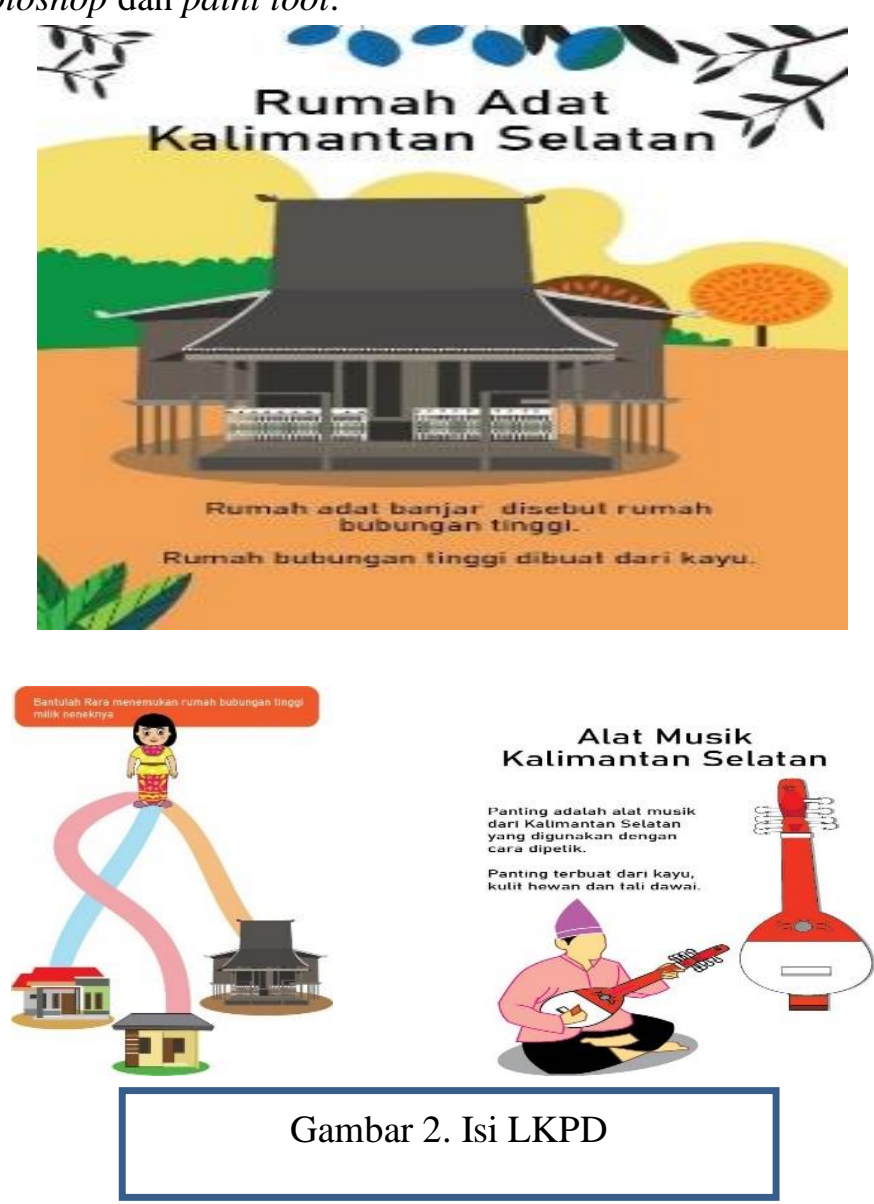

Setelah pendesainan LKPD berbasis budaya lokal selesai, kemudian dilanjutkan dengan pencetakan yang kemudian dievaluasi oleh ahli. Uji ahli dilakukan untuk mengevaluasi produk yang dikembangkan sebagai 
3504 Pengembangan Lembar Kerja Peserta Didik (LKPD) Bermuatan Budaya Lokal untuk Anak Usia DiniChresty Anggreani

DOI : https://doi.org/10.31004/edukatif.v3i6.882

bahan masukan untuk perbaikan produk. Hasil validasi tersebut berupa nilai dan saran perbaikan pada produk yang telah dikembangkan. Uji ahli pada penelitian ini terdiri dari: uji ahli materi, uji ahli media, dan uji ahli bahasa. Pada penilaian uji ahli materi rata-rata penilaian keseluruhan aspek sebesar 3 dengan indeks kelayakan sebesar 0,74. Adapun kelayakan penilaian oleh ahli materi dapat dilihat pada grafik di gambar 3 .

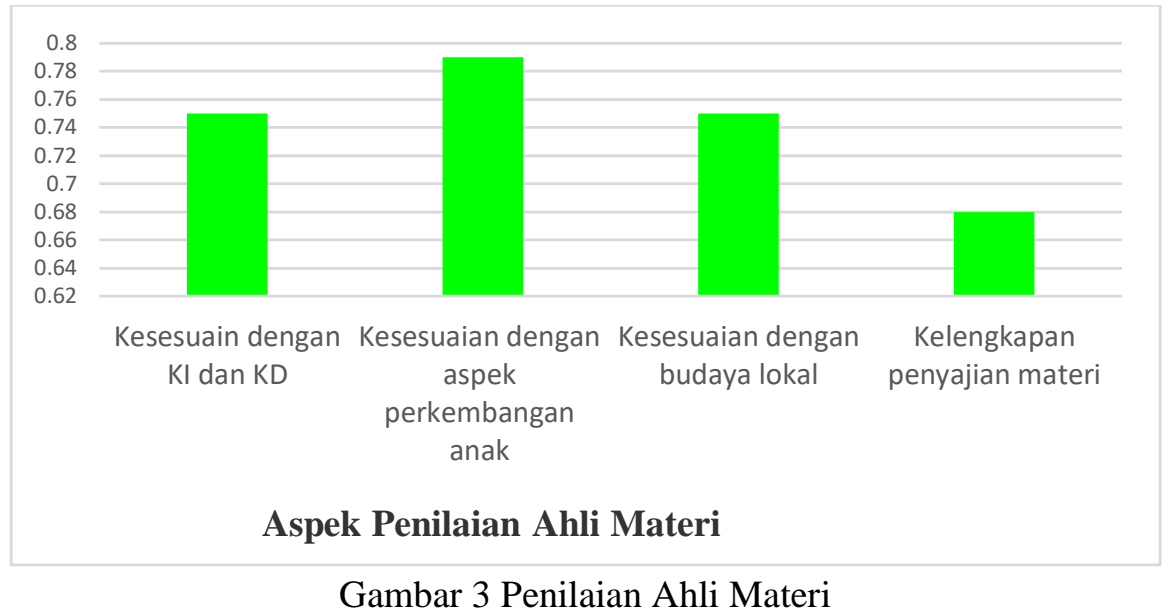

Gambar 3 Penilaian Ahli Materi

Dari gambar 3 terlihat penilaian ahli dari setiap aspek penilaian yaitu pada aspek kesesuaian dengan KI dan KD sebesar 3 dengan indeks kelayakan 0,75. Aspek kesesuaian dengan aspek perkembangan anak sebesar 3,1 dengan indeks kelayakan 0,79. Aspek kesesuaian dengan budaya lokal sebesar 3 dengan indeks kelayakan sebesar 0,75. Dan pada aspek kelengkapan penyajian materi sebesar 2,75 dengan indeks kelayakan sebesar 0,68 .

Penilaian produk dari ahli media secara keseluruhan aspek menunjukan rata-rata kelayakan sebesar 3,2 dengan indeks kelayakan sebesar 0,95. Masing-masing hasil penilaan pada setiap aspek tersebut yaitu pada aspek ukuran buku sebesar 3 dengan indek kelayakan 0,75, aspek desain sampul sebesar 2,6 dengan indeks kelayakan sebesar 0,6, dan aspek desain isi buku sebesar 3,5 dengan indeks kelayakan sebesar 0,8. Kelayakan penilaian ahli media dapat dilihat pada grafik di gambar 4.

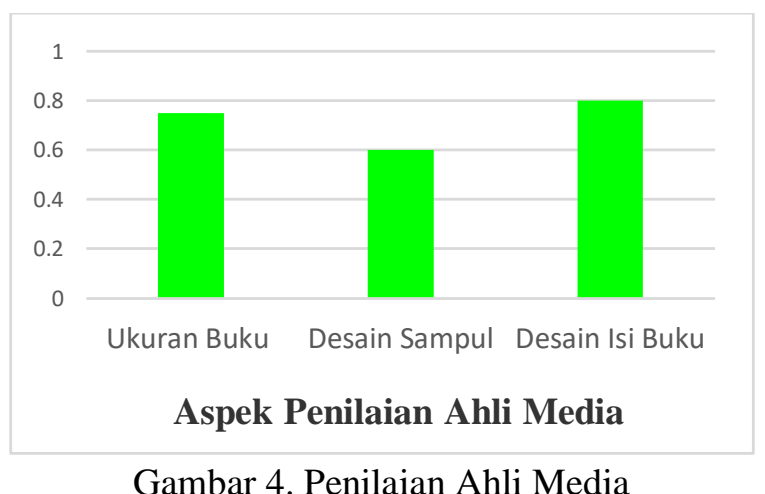

Penilaian produk pada ahli bahasa secara keseluruhan aspek sebesar 3,36 dengan indek kelayakan sebesar 0,8 . Untuk penilain ahli bahasa dapat dilihat pada grafik di gambar 5 . 
3505 Pengembangan Lembar Kerja Peserta Didik (LKPD) Bermuatan Budaya Lokal untuk Anak Usia DiniChresty Anggreani

DOI : https://doi.org/10.31004/edukatif.v3i6.882

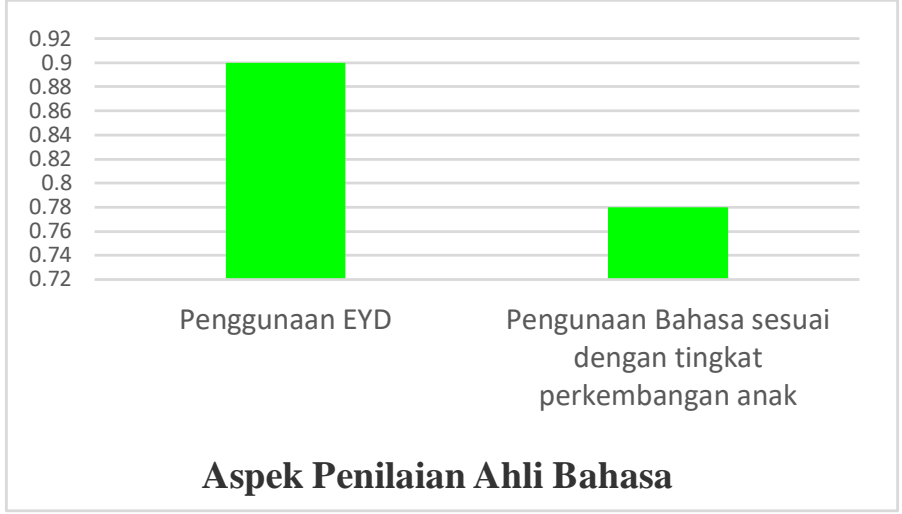

Gambar 5. Penilaian Ahli Bahasa

Dari gambar 5, terlihat penilaian ahli bahasa pada tiap-tiap aspek yaitu pada aspek penggunaan EYD sebesar 3,6 dengan indek kelayakan sebesar 0,9. Pada aspek penggunaan bahasa sesuai dengan tingkat perkembangan anak sebesar 3,25 dengan indeks kelayakan sebesar 0,8. Adapun beberapa Saran dari ahli materi, media, dan bahasa diantaranya yaitu: buku LKPD anak perlu menstimulasi higher order thinking anak usia dini, selain itu juga ukuran gambar yang masih terlalu kecil, sehingga perlu direvisi ukuran gambar dalam setiap buku aktivitas anak. Peneliti melakukan revisi berdasarkan saran dari para ahli materi, media, dan bahasa. Berdasarkan hasil penilaian dari ahli materi, ahli media, dan ahli bahasa dapat disimpulkan bahwa produk buku aktivitas anak dapat dilanjutkan pada tahap uji coba.

Keempat, pada tahapan ini dilakukan pengujian prototipe (one-to-one trying out) yang bertujuan untuk melihat kepraktisan dari produk yang telah dikembangkan. Uji coba ini dilakukan di kelompok B1 TK Pembina Banjarmasin Timur dengan subjek sebanyak 1 orang anak dan 3 orang anak yang kemampuan rendah, sedang, dan tinggi. Penilaian guru terhadap produk yang dikembangkan terdiri dari: 1) materi LKPD, 2) penyajian, dan 3) bahasa. Rata-rata hasil penilaian tersebut sebesar 2,9 dengan presentase presentase 72,1 berada pada kategori layak. Evaluasi hasil uji coba tahap one-to-one trying out dapat dilihat pada tabel 1, berikut:

Tabel 1. Rata-Rata Nilai Capaian Perkembangan Anak menggunakan LKPD Berbasis Budaya Lokal Kalimantan Selatan

\begin{tabular}{lllll}
\hline $\begin{array}{c}\text { Responde } \\
\text { n }\end{array}$ & \multicolumn{1}{c}{ Nilai } \\
\cline { 2 - 5 } $\mathbf{1}$ & 80 & 88 & 95 & \multicolumn{1}{c}{ Per 2 } \\
\hline $\mathbf{2}$ & 85 & 88 & 95 & 95,75 \\
\hline $\mathbf{3}$ & 90 & 80 & 90 & 90 \\
\hline Rerata & 85 & 85,3 & 93,3 & 89,25 \\
\hline Kategori & Baik sekali & Baik Sekali & Baik Sekali & Baik Sekali \\
\hline
\end{tabular}

Nilai rata-rata hasil observasi capaian pembelajaran anak menggunakan LKPD berbasis budaya lokal Kalimantan Selatan pada tabel 1 pertemuan 1 sebesar 85 dengan kategori baik sekali, petermuan 2 sebesar 85,3 dengan kategori baik sekali, dan pada pertemuan 3 sebesar 89,25. Adapun saran dari guru yaitu: 1) penyajian gambar yang harus memperhatikan pada unsur kesesuaian materi, warna, dan kemenarikan, 2) Beberapa halaman LKPD, bacaan teksnya terlalu panjang, dan ukuran fontnya terlalu kecil untuk anak. Kemudian peneliti merevisi LKPD berdasarkan pada saran tersebut, untuk dilanjutkan pada tahap uji coba kelompok kecil.

Tahap uji coba coba kelompok kecil (small group evalution). Uji coba kelompok kecil (small group evaluation) dilakukan kepada 12 orang anak. Tahapan dilakukan untuk melihat kepraktisan produk yang digunakan oleh anak. 
3506 Pengembangan Lembar Kerja Peserta Didik (LKPD) Bermuatan Budaya Lokal untuk Anak Usia DiniChresty Anggreani

DOI : https://doi.org/10.31004/edukatif.v3i6.882

Tabel 2 . Rata-Rata Nilai Capaian Perkembangan Anak menggunakan LKPD Berbasis Budaya Lokal Kalimantan Selatan

\begin{tabular}{|c|c|c|c|c|}
\hline \multirow[t]{2}{*}{ Responden } & \multicolumn{4}{|c|}{ Nilai } \\
\hline & Per 1 & Per 2 & Per 3 & Per 4 \\
\hline FA & 75 & 72 & 100 & 82 \\
\hline AZK & 60 & 92 & 100 & 88 \\
\hline SUL & 72 & 84 & 100 & 89 \\
\hline ECH & 95 & 88 & 80 & 81 \\
\hline AKB & 87 & 88 & 100 & 94 \\
\hline NAS & 95 & 68 & 90 & 88 \\
\hline ALK & 77 & 80 & 100 & 79 \\
\hline AEI & 72 & 88 & 55 & 79 \\
\hline $\mathbf{A Z Z}$ & 95 & 88 & 70 & 88 \\
\hline FAJR & 67 & 88 & 100 & 84 \\
\hline AQL & 72 & 96 & 100 & 92 \\
\hline ALE & 65 & 72 & 35 & 58 \\
\hline Rerata & 78 & 83,67 & 85,83 & 83 \\
\hline Kategori & Baik & Baik sekali & Baik sekali & Baik sekali \\
\hline
\end{tabular}

Nilai rata-rata hasil observasi keterlaksanaan pembelajaran pada uji coba lapangan pada tabel 2 dapat dilihat diatas bahwa pada subtema 1 petermuan 1 rata-rata nilai perolehan anak menggunakan LKPD sebesar 78 dengan kategori baik, pada subtema 2 petermuan 2 rata-rata nilai perolehan anak sebesar 83,67\% dengan kategori baik sekali, pada subtema 3 pertemuan 3 rata-rata nilai perolehan anak sebesar 85,83 dengan kategori baik sekali, dan pada pertemuan 4 rata-rata nilai perolehan anak sebesar 86,6 dengan kategori baik sekali.

Selanjutnya pada tahap uji coba ini juga dilakukan penghitungan validitas, reliablitas, dan indeks kesukaran soal yang ditentukan dari skor peroelhan anak setelah menjawab soal. Dalam hal ini validitas, reliabilitas, dan indeks kesukaran soal dihitung dengan menggunakan aplikasi IBM SPSS Statistic 26. Berdasarkan tabel ditas terlihat bahwa seluru item soal memiliki koefisien validitas yang lebih besar dari $\mathrm{r}$ kritis 0,3. Sehingga item-item tersebut layak digunakan sebagai alat ukur dalam penelitian. uji reliabiltas yang dilakukan terhadap soal yang dinyatakan valid. Jadi berdasarkan data diatas, koefisien reliabilitas soal lebih besar dari nilai "alpha Cronbach" lebih besar dari 0,600, sehingga item soal dinyatakan reliable atau memenuhi persyaratan. Dengan demikian, LKPD berbasis budaya lokal Kalimantan Selatan sangat efektif untuk digunakan di PAUD dalam mengembangkan aspek perkembangan anak. Hal ini seperti yang diungkapkan oleh Larasati \& Yulianti (2014) masa usia dunia merupakan masa pengembangan seluruh instrumen besar manusia terbentuk, baik fisik dan psikis. Hal ini dipertegas oleh Christianti (2012) bahwa melalui PAUD merupakan sarana untuk memfasilitasi pengembangkan pemikiran anak terhadap sekolah. Selanjutnya, Amirudin \& Widiati (2017) menyebutkan bahan ajar merupakan salah satu faktor yang menentukan keberhasilan pembelajaran. Lebih lanjut Nisa \& Supriyanto (2016) menyatakan bahan ajar merupakan komponen pembelajaran yang dipergunakan guru untuk membantu dalam pencapaian kompetensi anak. Dengan demikian, keberadaan LKPD dalam kegiatan pembelajaran sangat penting untuk membantu guru maupun anak.

Syarif et al (2016) menyebutkan pembelajaran berbasis budaya lokal berperan dalam pembinaan dan pembentukan sikap, mental dan moral manusia. Sedangkan Muzakki \& Fauziah (2015) berpendapat bahwa bentuk pelestarian pada budaya lokal dapat dilakukan melalui pembelajaran. Untuk itu, dalam pembelajaran di PAUD perlunya memuat unsur-unsur budaya melalui tema-tema pembelajaran sebagai langkah awal untuk mengenalkan budaya kepada anak melalui kegiatan yang menyenangkan. Setelah produk melalui tahap uji coba dan revisi serta mendapatkan hasil perhitungan yang menyatakan bahwa produk telah valid dan praktis, maka LKPD berbasis muatan lokal Kalimantan Selatan siap untuk untuk diproduksi secara masal. 
3507 Pengembangan Lembar Kerja Peserta Didik (LKPD) Bermuatan Budaya Lokal untuk Anak Usia DiniChresty Anggreani

DOI $\quad$ : https://doi.org/10.31004/edukatif.v3i6.882

Merujuk pada penelitian dari (Firdaus \& Wilujeng, 2018) bahwa LKPD merupakan perangkat pembelajaran yang digunakan guru dalam proses pembelajaran dikelas. Selanjutnya dalam penelitan (Yuantini et al., 2019) LKPD dapat memudahkan guru dalam menjelaskan materi budaya kepada anak. Peneliti dan peneliti terdahulu menyepakati bahwa penggunaan LKPD sebagai sumber belajar dapat memudahkan anak dalam mengenal budayanya dan sebagai alat bantu guru untuk menyampaikan konsep kepada anak. Kelebihan dari produk LKPD ini yaitu memuat materi yang berbasis budaya lokal Kalimantan Selatan untuk memenuhi kebutuhan bahan ajar yang sesuai dengan .lingkungan anak. Dengan adanya bahan ajar yang berbasis budaya lokal ini, diharapkan dapat menanamkan rasa cinta anak terhadap budayanya dan sebagai bentuk pelestaria budaya untuk mencegah terjadinya kepunahan budaya. Oleh karena itu, perlunya penciptaan media pembelajaran dalam bentuk lain yang inovatif dan komunikatif untuk mendukung pengenalan budaya yang sesuai dengan karakteristik pembelajaran pada anak usia dini.

\section{KESIMPULAN}

Pengembangan LKPD berbasis budaya lokal yang dikembangkan dalam penelitian ini telah memenuhi kriteria valid, praktis dan efektif berdasarkan hasil uji coba di kelompok B TK Pembina Banjarmasin Timur. Dengan demikian, buku aktivitas anak berbasis budaya lokal Kalimantan Selatan ini layak digunakan guru sebagai tambahan sumber belajar untuk mengembangkan aspek perkembangan anak. Berdasarkan hasil penelitian yang telah dilakukan pada pengembangan LKPD bermuatan budaya lokal Kalimantan Selatan dharapkan dapat digunakan sebagai media pembelajaran pada pengenalan materi tanaman untuk mengembangkan aspek perkembangan anak yaitu aspek perkembangan nilai, agama dan moral, aspek perkembangan bahasa, aspek perkembangan kognitif, aspek perkembangan sosial emosional, aspek perkembangan fisik motorik, dan aspek perkembangan bahasa. LKPD berbasis budaya Lokal anak yang dikembangkan oleh peneliti masih terbatas pada lingkup budaya lokal Kalimantan Selatan dan tema tanaman saja, hendaknya untuk penelitian selanjutnya bisa dikembangkan LKPD anak pada budaya lokal dari berbagai dearah dan pada tema-tema yang lebih banyak yang sesuai dengan kebutuhan anak.

\section{DAFTAR PUSTAKA}

Amirudin, A., \& Widiati, U. (2017). Pentingnya Pengembangan Bahan Ajar Tematik Untuk Mencapai Pembelajaran Bermakna Bagi Siswa Sekolah Dasar. Prosiding Seminar Nasional Mahasiswa Kerjasama Direktorat Jenderal Guru Dan Tenaga Kependidikan Kemendikbud 2016.

Ariyanti, T. (2016). Pentingnya Pendidikan Anak Usia Dini Bagi Tumbuh Kembang Anak The Importance Of Childhood Education For Child Development. Dinamika Jurnal Ilmiah Pendidikan Dasar, 8(1).

Brata, I. B. (2016). Kearifan Budaya Lokal Perekat Identitas Bangsa. Jurnal Bakti Saraswati (Jbs), 5(1).

Christianti, M. (2012). Profesionalisme Pendidik Anak Usia Dini. Jurnal Pendidikan Anak, 1(1).

Firdaus, M., \& Wilujeng, I. (2018). Pengembangan Lkpd Inkuiri Terbimbing Untuk Meningkatkan Keterampilan Berpikir Kritis Dan Hasil Belajar Peserta Didik. Jurnal Inovasi Pendidikan Ipa, 4(1), 2640.

Fitriani, F., Hasan, M. H. M., \& Musri, M. (2016). Pengembangan Lembar Kegiatan Peserta Didik (Lkpd) Berbasis Masalah Untuk Meningkatkan Pemahaman Konsep Dan Aktivitas Belajar Peserta Didik Pada Materi Larutan Penyangga. Jurnal Pendidikan Sains Indonesia (Indonesian Journal Of Science Education), 4(1).

Herman, H., \& Aslim, A. (2015). Pengembangan Lkpd Fisika Tingkat Sma Berbasis Keterampilan Proses Sains. Prosiding Seminar Nasional Fisika (E-Journal), 4, Snf2015-Ii. 
3508 Pengembangan Lembar Kerja Peserta Didik (LKPD) Bermuatan Budaya Lokal untuk Anak Usia DiniChresty Anggreani

DOI $\quad$ : https://doi.org/10.31004/edukatif.v3i6.882

Hulu, G., \& Dwiningsih, K. (2021). Validitas Lkpd Berbasis Blended Learning Berbantuan Multimedia Interaktif Untuk Melatihkan Visual Spasial Materi Ikatan Kovalen. Unesa Journal Of Chemical Education, 10(1), 56-65.

Islamiah, F., Fridani, L., \& Supena, A. (2019). Konsep Pendidikan Hafidz Qur'an Pada Anak Usia Dini. Jurnal Obsesi: Jurnal Pendidikan Anak Usia Dini, 3(1), 30-38.

Larasati, A., \& Yulianti, D. (2014). Pengembangan Bahan Ajar Sains (Fisika) Tema Alam Semesta Terintegrasi Karakter Dan Berwawasan Konservasi. Upej Unnes Physics Education Journal, 3(2).

Mubah, A. S. (2011). Strategi Meningkatkan Daya Tahan Budaya Lokal Dalam Menghadapi Arus Globalisasi. Jurnal Unair, 24(4), 302-308.

Muzakki, M., \& Fauziah, P. Y. (2015). Implementasi Pembelajaran Anak Usia Dini Berbasis Budaya Lokal Di Paud Full Day School. Jppm (Jurnal Pendidikan Dan Pemberdayaan Masyarakat), 2(1), 39-54.

Nisa, H. U., \& Supriyanto, T. (2016). Pengembangan Bahan Ajar Membaca Sastra Legenda Bermuatan Kearifan Lokal Berbahasa Jawa. Seloka: Jurnal Pendidikan Bahasa Dan Sastra Indonesia, 5(2), 192 200.

Noprinda, C. T., \& Soleh, S. M. (2019). Pengembangan Lembar Kerja Peserta Didik (Lkpd) Berbasis Higher Order Thinking Skill (Hots). Indonesian Journal Of Science And Mathematics Education, 2(2), 168-176.

Rahayu, D. (2018). Pengembangan Lembar Kerja Peserta Didik (Lkpd) Berbasis Pemecahan Masalah Materi Bangun Datar. Jurnal Penelitian Pendidikan Guru Sekolah Dasar, 6(3).

Setyaningrum, N. D. B. (2018). Budaya Lokal Di Era Global. Ekspresi Seni: Jurnal Ilmu Pengetahuan Dan Karya Seni, 20(2), 102-112.

Syarif, E., Sumarmi, S., Fatchan, A., \& Astina, I. K. (2016). Integrasi Nilai Budaya Etnis Bugis Makassar Dalam Proses Pembelajaran Sebagai Salah Satu Strategi Menghadapi Era Masyarakat Ekonomi Asean (Mea). Jurnal Teori Dan Praksis Pembelajaran Ips, 1(1), 13-21.

Wandari, A., Kamid, K., \& Maison, M. (2018). Pengembangan Lembar Kerja Peserta Didik (Lkpd) Pada Materi Geometri Berbasis Budaya Jambi Untuk Meningkatkan Kreativitas Siswa. Edumatika: Jurnal Riset Pendidikan Matematika, 1(2), 47-55.

Wijiningsih, N., Wahjoedi, W., \& Sumarmi, S. (2017). Pengembangan Bahan Ajar Tematik Berbasis Budaya Lokal. Jurnal Pendidikan: Teori, Penelitian, Dan Pengembangan, 2(8), 1030-1036.

Yuantini, G., Hasmalena, H., \& Syafdaningsih, S. (2019). Pengembangan Lkpd Tema Tanah Airku Sub Tema Kota Palembang Untuk Anak Kelompok B. Jeced: Journal Of Early Childhood Education And Development, 1(2), 129-141. 